\title{
BUENOS AIRES NEGRA
}

SECRETO, María Verónica. Negros em Buenos Aires. Rio de Janeiro: Mauad Editora, 2013. 127p.

C omo María Verónica Secreto aponta na introdução de seu novo livro, durante a maior parte do século $\mathrm{XX}$ os historiadores deram pouca ou nenhuma atenção à presença africana e afrodescendente no Rio da Prata. Ao longo dos últimos vinte anos, porém, uma nova conjuntura se desenvolveu, à medida que estudiosos na Argentina e no Uruguai produziram uma série de pesquisas monográficas e coletâneas sobre a história e a cultura negras nesses países. $\mathrm{Ne}$ gros em Buenos Aires é um acréscimo valioso a esse movimento.

$\mathrm{O}$ último dos quatro capítulos do livro, "Imagens deslocadas", aborda os conhecidos silenciamento e invisibilização do passado dos negros de Buenos Aires. Examinando uma série de pinturas e publicações que apresentam imagens de africanos e afro-argentinos, Secreto verifica que quase todos datam da primeira metade do Oitocentos; isso a leva a concluir (corretamente, em minha opinião) que o processo de invisibilização ocorreu entre as últimas décadas do século XIX e as primeiras do XX. Até então, afrodescendentes eram bastante visíveis na vida da cidade e, consequentemente, nas fontes pictóricas e arquivísticas que documentam aqueles anos.

Um curioso deslize nesse capítulo é a atribuição do que suponho ser um título incorreto para a sugestiva pintura de Prilidiano Pueyrredón retratando uma mulher negra bem-vestida andando pela rua, seguida por um empregado branco. Secreto observa que "por algum motivo Prilidiano Pueyrredón chamou esse quadro de $O$ racismo após a liberdade" (p.100). Jamais vi esse título atribuído ao quadro, que o pintor na verdade denominou Esquina portenha. Tampouco era sua intenção sugerir racismo, antes o oposto: "nossas tradições ultrademocráticas [...] não só libertaram os escravos, como também forneceram-lhes criados de raça caucasiana" (para apreciar esta cativante imagem, ver http://naon2.com/hist/nov02/htms/ nov02_042esp.htm).

Os outros três capítulos do livro lançam mão de fontes de arquivo para examinar várias formas de protagonismo africano e afro-ar-

1 Felix Luna et al., Prilidiano Pueyrredón (Buenos Aires: Banco Velox, 1999), p.67. 
gentino durante o meio século que corre entre 1770 e 1820 . O capítulo 1 examina os esforços de escravos para obter a liberdade por meio da compra da alforria (paga por si ou por terceiros) e, mais frequentemente, para melhorar sua posição no interior do escravismo, por meio da troca de senhores. As leis espanholas e coloniais garantiam ambos os direitos (tanto o de comprar a própria alforria, quanto o de buscar um novo senhor), e o livro de Secreto pode ser lido como um contributo à reabilitação da tese de Tannenbaum, atualmente em curso nos estudos afro-latinos. Ao codificar esses e outros direitos, e ao permitir aos escravos o acesso a autoridades reais, algumas das quais estavam comprometidas com o cumprimento dessas leis, as instituições espanholas criaram espaços nos quais os escravos podiam buscar, se não a liberdade propriamente dita, um cativeiro mais tolerável. Embora alguns senhores aceitassem tais leis e os princípios que as regiam, outros partiam para o combate. Secreto dá particular atenção ao caso do Coronel Cornelio Zelaya e de sua escrava Marta (pp. 41-46, 65-71). Alegando punição excessiva, Marta encontrou outro senhor disposto a comprá-la, mas não pelos 400 pesos que Zelaya exigia. Recorrendo às autoridades, Marta conseguiu reduzir a 200 pesos o valor a ser pago pela alforria; Zelaya, por sua vez, recorreu da decisão e aparentemente venceu o litígio, de modo que Marta foi "con- denada à escravidão novamente" (p.71). Mas, onde Marta perdeu, outros escravos foram bem-sucedidos, obtendo de fato o direito de mudar de senhor ou de escapar completamente à escravidão.

No capítulo 2, Secreto examina casos de negros livres reclamando reparação de ofensas a tribunais reais ou autoridades. Em um desses casos, o sargento-mor Manuel Farias, da Companhia dos Negros Livres, queixou-se ao vice-rei de que um dos seus subordinados, Pablo Aguero, tinha desacatado sua autoridade e, por extensão, a do próprio vice-rei. A investigação subsequente esmiuçou outras dimensões da vida dos negros em Buenos Aires: capitães do mato, negros autorizados a caçar e prender escravos fugidos; nações africanas, sociedades de ajuda mútua baseadas nas identidades étnicas africanas de seus membros; e disputas pelo poder entre distintas figuras de autoridade na comunidade negra. ${ }^{2}$ Num outro episódio, 48 sapateiros negros e mulatos requereram da Coroa a permissão para abandonar a corporação de que participavam e fundar uma organização própria. O motivo, afirmavam,

\footnotetext{
O texto completo da denúncia de Farias, e a posterior investigação oficial, está disponível (em inglês e espanhol) em Patricia Fogelman e Marta Goldberg, "'El rey de los congos': The Clandestine Coronation of Pedro Duarte in Buenos Aires, 1787," in Kathryn Joy McKnight e Leo Garofalo (eds.), Afro-Latino Voices: Narratives from the Early Modern Ibero-Atlantic World, 1550-1812 (Indianapolis: Hackett Publishing Company, 2009), pp.155-73.
} 
era poupar seus colegas brancos da "bochornosa confusión" // "vexatória confusão" // de ter de partilhar sua guilda com negros livres e escravos, "lo que sería cosa extraña e indecente" // "o que seria coisa estranha e indecente" // para os artesãos brancos (p.61). Na realidade, os reclamantes tentavam garantir o direito de eleger seus próprios oficiais e conformar suas próprias estruturas de autoridade, opções que lhes eram negadas sob os ditames raciais que governavam as corporações de ofício.

Negros em Buenos Aires oferece evidência abundante das iniciativas de negros, escravos ou livres, e da persecução ativa de seus objetivos individuais e coletivos. Embora as leis e instituições coloniais procurassem mantê-los em posição de subordinação e inferioridade, forneciam-lhes, por outro lado, armas e oportunidades para redefinir sua opressiva situação e, em alguns casos, libertar-se. Nesse sentido e apesar de suas inegáveis especificidades locais, Buenos Aires termina parecendo-se// tornase // bem semelhante a outras cidades do período colonial tardio, como Rio de Janeiro, Salvador, Havana ou Cartagena - nas quais africanos e seus descendentes estavam incessantemente manobrando e negociando em busca por liberdade e igualdade. Mais uma razão, portanto, para reconhecer e celebrar a rica história portenha de iniciativa e luta negra, um objetivo para o qual este livro contribui de forma admirável.

George Reid Andrews
reid1@pitt.edu
University of Pittsburgh 